\title{
Critical success factors influencing e-commerce adoption in SMEs: A review and model
}

\author{
Fatima Ajmal*, Norizan Mohd Yasin, Azah Anir Norman
}

Department of Information System, Faculty of Computer Science and Information Technology, University Malaya, Kuala Lumpur, Malaysia

\section{A R T I C L E I N F O}

\section{Article history:}

Received 16 February 2017

Received in revised form

27 April 2017

Accepted 23 May 2017

\section{Keywords:}

E-commerce

Success factors

SMEs

Adoption model

Review

\begin{abstract}
A B S T R A C T
This paper attempts to identify and evaluate the success factors that influence e-commerce adoption in SMEs and develop a conceptual model based on identified factors. A detailed literature search covering the past 26 years has been conducted. This literature search results in finding a total of 32 critical success factors of e-commerce in SMEs that are divided into seven main categories, namely: technical, individual, implementation, environmental, security, privacy, and organization. This paper will list, discuss, analyse, and evaluate these e-commerce success factors and explains how it will allow business to integrate e-commerce in their businesses.

(C) 2017 The Authors. Published by IASE. This is an open access article under the CC BY-NC-ND license (http://creativecommons.org/licenses/by-nc-nd/4.0/).
\end{abstract}

In this paper, e-commerce success factors for

\section{Introduction}

Electronic-commerce (e-commerce) refers to conducting business among firms with the support of a network of Information and Communication Technologies (ICT); particularly the internet. Ecommerce consists of Electronic Data Interchange (EDI), EFTPOS (Electronic Fund Transfer at Point of Sale); electronic fund transfer (EFT), electronic banking, digital cash, and other forms of electronic payment systems. It is used to enhanced transactions and communications between stakeholders, such as customers, suppliers, business partners, managers, employees, the general public, financial institutions, and government regulators. E-commerce has provided a tremendous amount of benefits to Small and Medium-sized Enterprises (SMEs). As ecommerce continues to evolve, it has provided a number of research opportunities for the Information System (IS) community. E-commerce not only helps large businesses to increase their visibility and profits, it also helps SMEs to achieve all of those benefits. In this economic period of time, SMEs contribute to economic growth, social structure, employment, as well as regional and local development. Consequently, they have become an important sector of the economy (Turban and King, 2004).

\footnotetext{
* Corresponding Author.

Email Address: fatima_ajmal@siswa.um.edu.my (F. Ajmal) https://doi.org/10.21833/ijaas.2017.07.023

2313-626X/C 2017 The Authors. Published by IASE.

This is an open access article under the CC BY-NC-ND license

(http://creativecommons.org/licenses/by-nc-nd/4.0/)
} SMEs are reviewed. The review is based on various journal papers and articles that are related to ecommerce, over the last 23 years. Given the sheer volume of e-commerce research in this area, it seems obvious that surveying, interpreting, and analysing this literature should be done. The objective of this paper is firstly to identify critical factors that can affect businesses toward the adoption of ecommerce in their respective organizations/companies. An secondly, to develop a conceptual model for e-commerce adoption for SMEs, that is relevant to the technical, individual, implementation, environmental, trust and organizational factors that affect SME's decision to adopt e-commerce.

The remainder of the paper is structured as follows: The following section will include a brief review of relevant literature on E-commerce, SMEs and E-commerce within SMEs. This is followed by a review of the methodology and conceptual framework for e-commerce and the success factors will be explained. The final section provides a conclusion along with suggestions for future research.

\section{Theoretical background}

\subsection{E-commerce}

With the advent of the internet and its commercialization since 1994, a new medium of commerce, popularly known as E-commerce, has rapidly emerged into a modern global economy (Vaithianathan, 2010). E-commerce is the process of 
buying, selling, or exchanging products, services, and information, using computer networks; including the internet (Turban et al., 2011). Globalization of the internet and the World Wide Web (WWW) has driven e-commerce to be one of the most effective media for sharing information. It has revolutionised businesses, as it allows the sharing of information between business partners and organizations (Turban and King, 2004). E-commerce has changed, and is still changing the way companies are conducting business globally (Chong et al., 2001; Mazzarol, 2015).

Over the last 22 years (since the growth of the internet in 1990's), there has been a great deal of interest in the internet and e-commerce, where ecommerce has gained substantial media and trade attention. The internet has continued to grow since 1990 (Anumba and Ruikar, 2002), but e-commerce was only able to gain exposure around the time of the dotcom boom and crash (1999) (Ngai and Wat, 2002). Although the starting dates for articles was set to be 1991, papers related to e-commerce can be found from 1993 onwards, as this was the year that businesses started making use of the term ecommerce. Articles before 1993 are mostly related to EDI and internet adoption, as these were the frequently used terms at that time to define ecommerce (Kosiur, 1997). Currently, almost all medium to large enterprises have websites and portals to connect their suppliers and business partners together. Since 2000, there has been a greater emphasis on small and medium sized enterprises towards the adoption of e-commerce in their respective industries, and several researches have been conducted in this sector to improve the adoption process at a managerial level (Turban and King, 2004). From 2000 to 2013, extensive research was conducted by various researchers to improve ecommerce adoption among businesses (as shown in Table 1). For this reason, January 2013 was chosen as the end date for this research.

With all of this said however, there remains a high tendency to not use the Internet when it comes to performing business transactions. A lack of trust on the part of internet users and SMEs when it comes to e-commerce is often assumed to be one of the many reasons for the disappointing development of Business to Consumers (B2C) in e-commerce (Reichheld and Schefter, 2000; Karimov et al., 2011). This lack of trust is thought to have many causes, and most literature centres on a perceived lack of security in Internet transactions, together with the fear of loss of privacy (Zhou et al., 2008; AldásManzano et al., 2009; Polasik and Piotr Wisniewski, 2009; Zendehdel and Paim, 2012). As a direct result of these problems, e-commerce cannot grow at a rapid pace (Zendehdel and Paim, 2012). Therefore, from 2010, there has been an increase in research focussing on e-commerce security so as to encourage people to spend online by trusting the vendor. Table 1 describes in detail what happened in each year from 1991 to 2017.

The distribution of articles (sorted by publication date) is shown in Table 1 . The Table 1 shows that there were fewer articles found on the topic of ecommerce success factors in SMEs from 1991 to 2000. However, the author found that from 2001 to 2017 , there were a considerable number of articles published.

Table 1: E-commerce evolution

\begin{tabular}{|c|c|}
\hline Year & E-commerce usage \\
\hline \multirow{3}{*}{1991} & Electronic data interchange \\
\hline & Internet adoption \\
\hline & The Internet fell into common use by companies. \\
\hline \multirow{2}{*}{1992} & Electronic data interchange \\
\hline & Internet adoption \\
\hline \multirow{2}{*}{1993} & Business starts making use of the term e-commerce. \\
\hline & The first web browser NCSA Mosaic was developed, thus bringing businesses and people to the web (Vladimir, 1996). \\
\hline 1994 & Online ordering and subscription began \\
\hline 1995 & Innovation of Internet application \\
\hline \multirow[t]{2}{*}{ 1996-1998 } & Websites continue to grow \\
\hline & Dot-com boom \\
\hline \multirow[t]{2}{*}{1999} & Peer-to-peer sharing website developed \\
\hline & The emphasis of e-commerce shifted from Business- to-Consumer to Business-to-Business. \\
\hline \multirow{2}{*}{2000} & Dot-com bust \\
\hline & $\begin{array}{l}\text { Business started associating the term e-commerce with selling and purchasing products online using secure protocol and } \\
\text { payment }\end{array}$ \\
\hline \multirow[t]{2}{*}{2001} & $\begin{array}{l}\text { Consumer-to-Consumer (C2C), Business-to-Employee (B2E), e-commerce, e-government and e-learning began to gain } \\
\text { popularity }\end{array}$ \\
\hline & SMEs placed great emphasis on the adoption of e-commerce \\
\hline \multirow[t]{2}{*}{$2002-2010$} & Extensive research conducted by businesses regarding the adoption of e-commerce in their respective organizations \\
\hline & The research in e-commerce continued to grow. Most large businesses owned their own website which connects their \\
\hline \multirow[t]{2}{*}{ 2011-2017 } & $\begin{array}{l}\text { employees, business partners and customers to their services and allows them to access information. } \\
\text { The Internet and e-commerce will continue to change in the future. }\end{array}$ \\
\hline & Increase focus on security and privacy aspects of e-commerce to encourage consumers to spend more on Internet. \\
\hline
\end{tabular}

\subsection{Small and medium-sized enterprises (SMEs)}

The definition of SMEs varies from industry to industry and country to country. However, they are generally based on the number of people employed, turnover, and/or the ownership structure of the business (Ayyagari et al., 2007; Poon, 2002). Some definitions of SMEs have been offered in quantitative terms, whilst others have been presented in qualitative terms. According to some researchers, 
the definition should involve both the quantitative dimension, such as the number of employees, measures of transactions, financial and non-financial resources, and liquidity; and the qualitative dimension, such as the method of organizing and function performance (McGregor and Vrazalic, 2007). However, mostly it depends on the number of employees in an SME as an upper and lower size limit of an SME. Most resources define an SME's cutoff range as 0-250 employees, where it can involve a single part-time owner of business to a professional organization employing up to 250 people (Seyal et al., 2012; ABS, 2013).

Different characteristics distinguish SMEs from large corporations, as they are not a scale down version of a large company. SMEs are generally independent, multi-tasking, cash-limited, ownerbased, and actively managed by the owners, highly personalized and informal structure; largely localize enterprises in their area of operations that are largely dependent on internal sources to the growth of finance (Perrini et al., 2007; Jahanshahi et al., 2013).

\subsection{E-commerce in SMEs}

SMEs play a basic role in the improvement and promotion of economic indices of a major economic sector of any country, and therefore, adopting creative and modern methods and tools for performing business processes and affairs, plays an important role in the success of any organization (Abbasi et al., 2010; Ale Ebrahim, 2010). SMEs are interested in e-commerce because it can help them to improve their business processes, reduce costs, and achieve a closer relationship with their clients. Beyond this, the adoption of e-commerce in SMEs has become a necessity in the context of globalized markets (Neergaard, 1992; Huy and Filiatrault, 2006).

Nobody can deny the fact that SMEs play an important role in both developed and developing countries (Savrul et al., 2014). It should be noted that many potential benefits can be created by ecommerce, but the adoption of e-commerce in SMEs is still limited (Grandon and Pearson, 2004; Jahanshahi et al., 2013). This is because SMEs are waiting to see whether e-commerce is viable or not and whether returns on investment will exceed the adoption of these new technologies (Dholakia and Kshetri, 2004).

\section{Methodology}

This review covers 26 years of research, between 1991 and 2017. 1991 is referred to as a start data of the literature search, as according to Anumba and Ruikar (2002), it was around this time that ecommerce began being used by businesses. In order to find relevant articles, we performed a full-text search, to minimize the risk of omitting relevant articles. To find relevant articles, multidisciplinary databases were used, such as Emerald, Journal
Storage (JSTOR), ISI Web of Science, ScienceDirect, SpingerLink, and Google Scholar. Table 2 shows the journals and the specific number of articles taken from them.

The search terms used corresponded to the terms shown in Fig. 1, such as e-commerce, success factors of e-commerce, and e-commerce success factors in SMEs. Using these keywords, we were able to find 1,490 articles. After reading through several papers, a total of 323 articles were identified that matched the topic area, and were read thoroughly. A table was created showing which papers were only related to e-commerce success factors in SMEs. A total of 40 papers that matched those criteria were then evaluated one by one and the success factor of each paper was identified and analysed.

Articles were collected from reputed journals, books and practitioners' literatures related to the topic, which were published since 1991. Unpublished papers or dissertations were not included due to quality concerns. The articles exclusively related to Business-to-consumer (B2C) ecommerce and the articles related to Business-toBusiness (B2B), and Consumer-to-Business (C2B) was not included in this research. This is because the determinants of success factors were likely to be different in $\mathrm{B} 2 \mathrm{~B}$ and $\mathrm{C} 2 \mathrm{C}$ environments than that of B2C; in terms of customer type, trade/sales, business and decision making. The review covered research conducted in different regions/countries to get a better overall understanding of success factors in SMEs; as illustrated in Fig. 2. Fig. 2 shows that more developed countries, such as United States of America (USA), United Kingdom (UK), Singapore, and Australia, have more papers published on this topic compared with other developing countries, such as Malaysia, Thailand, China, India Vietnam, and Italy. This study provides a comprehensive understanding of the topic area, so that the success factors of e-commerce in SMEs can be identified.

\section{E-commerce success factor model}

During the literature review, 32 factors were identified. These factors were divided into independent factors that were Organizational, Management, Technological, Individual, Implementation, Trust, or Environmental. The technological factor is a self-made factor to categorize other factors, such as business infrastructure, technical infrastructure, and communication under one heading. Fig. 3 shows the distribution of articles by factor; as factors that were mentioned most frequently in technological papers, followed by environmental in e-commerce. Meanwhile, the least mentioned factor of all was Management. Each independent factor consisted of variable or dependent (contributing) factors. These factors were turned into a conceptual framework for e-commerce adoption in SMEs, as shown in Fig. 4. Table 2 shows the articles from where each individual variable was taken. Each of these factors 


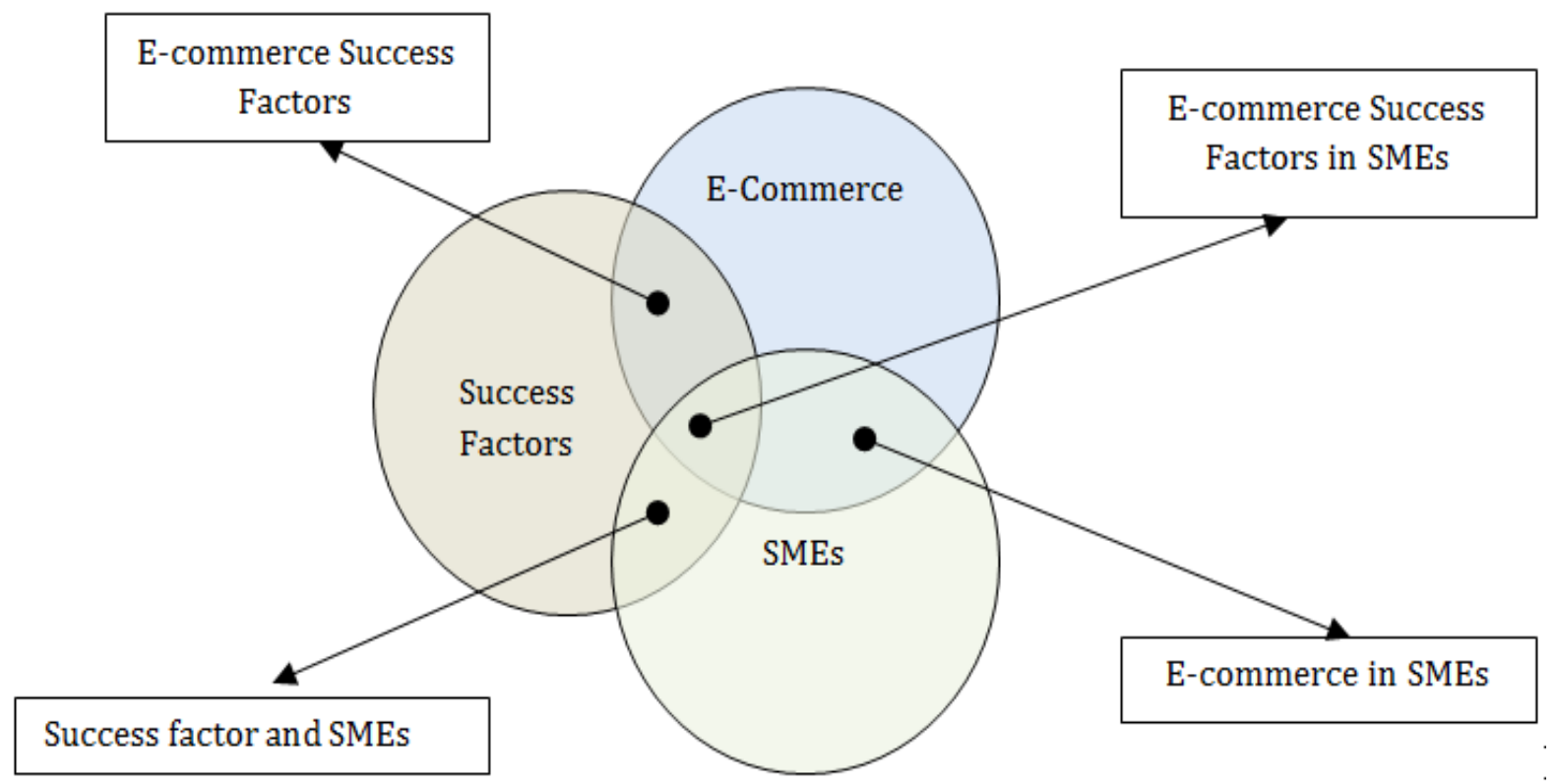

Fig. 1: Literature search keyword used in this paper

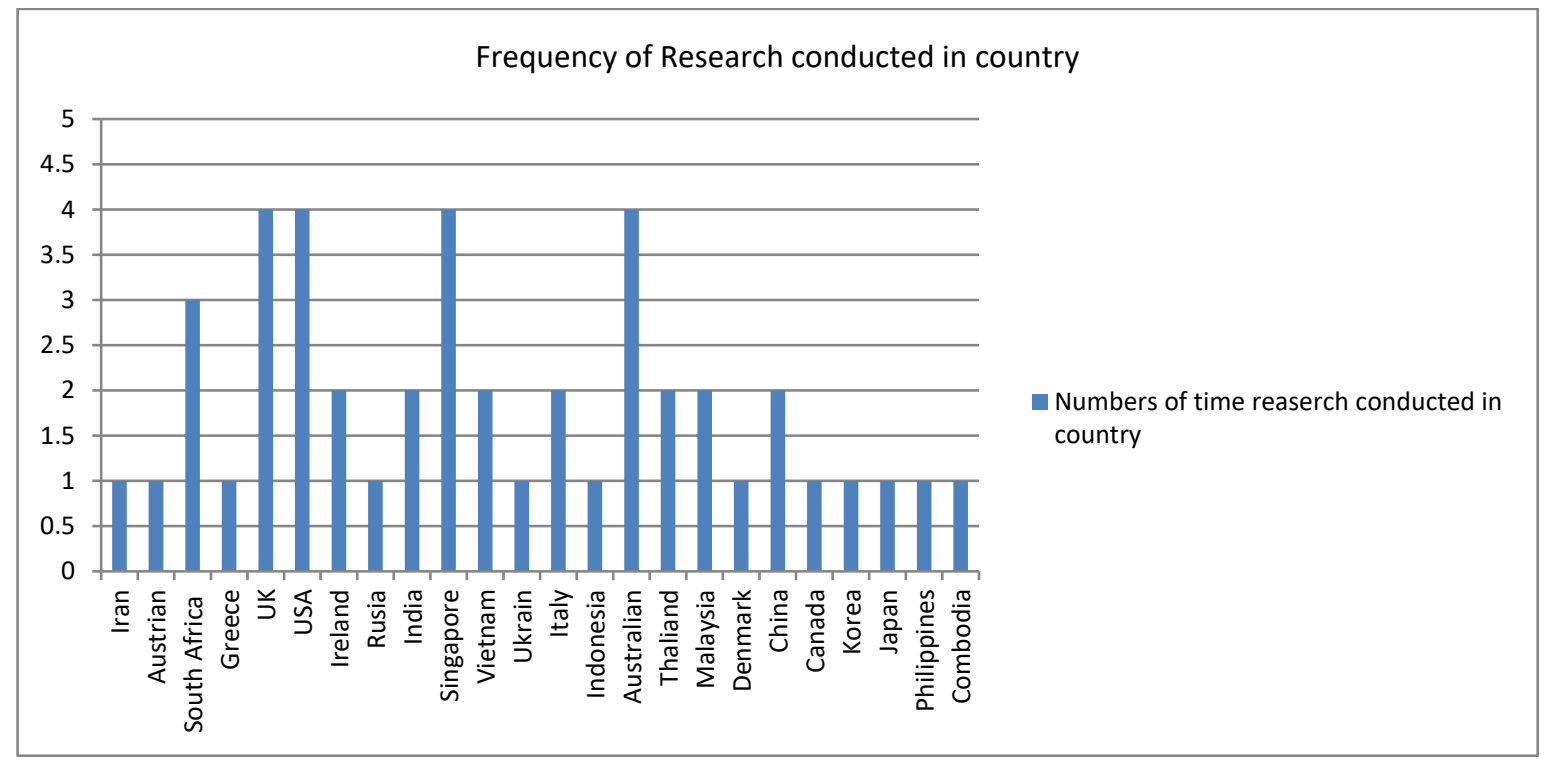

Fig. 2: Frequency of research conducted in country

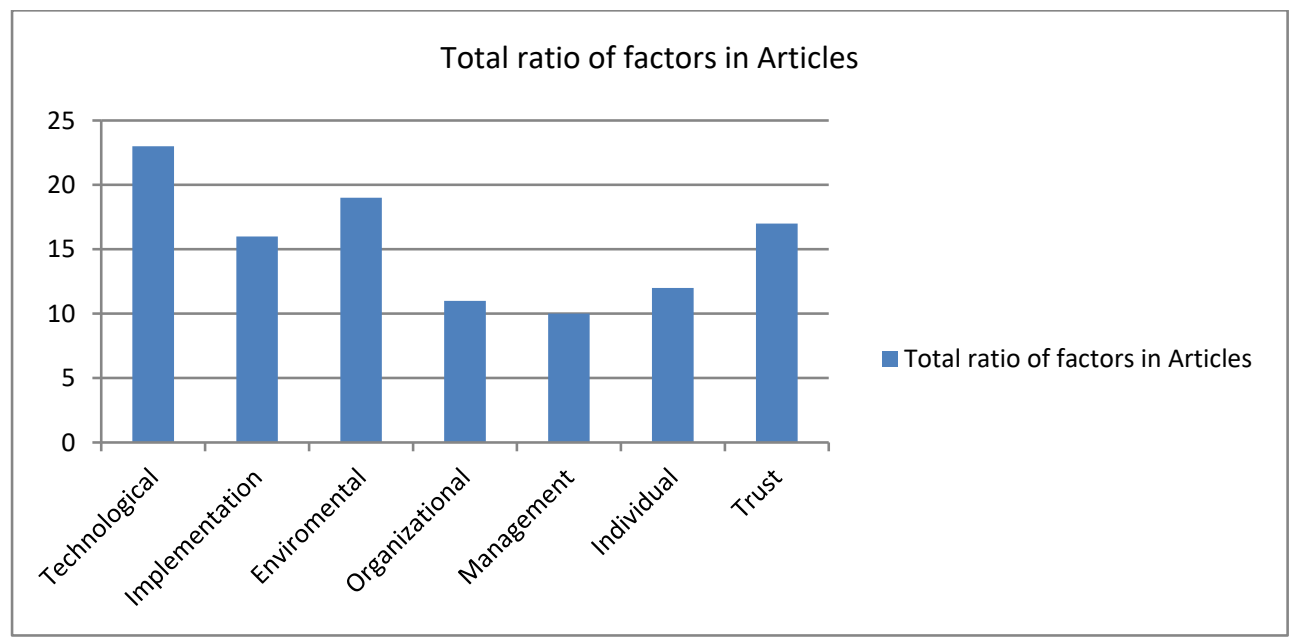

Fig. 3: Total ratio of factors found in the article 
Table 2: Classification of reviewed Literature

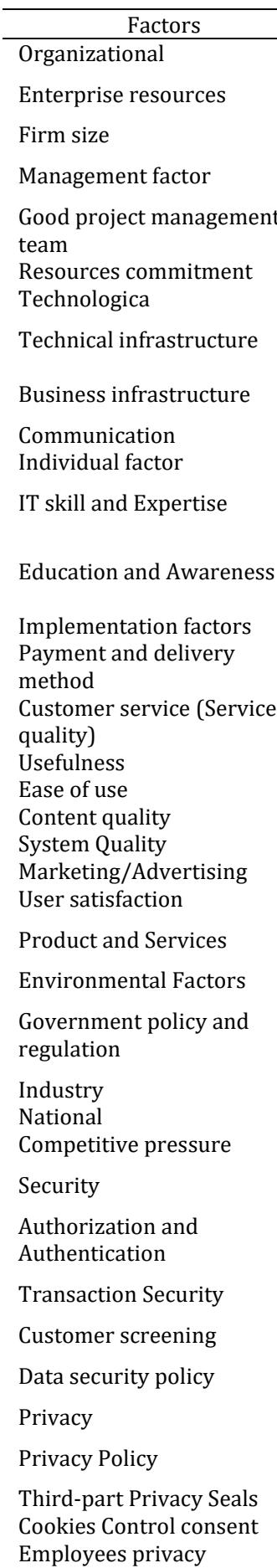
Reference (Teo et al., 1997; Ling, 2001; Rashid, 2001; Golden et al., 2004)

(Quayle, 2002; Kuzic et al., 2002; Sharma and Wickramasinghe, 2004; Huy and Filiatrault, 2006; Todd and Javalgi, 2007)

(Dholakia and Kshetri, 2004; Huy and Filiatrault, 2006; Tetteh, 1999)

(Tan and Teo, 1998; Quayle, 2002; Kuzic et al., 2002; Golden et al., 2004; Poon and Huang, 2004; Sharma and Wickramasinghe, 2004; Huy and Filiatrault, 2006)

(Lowry et al., 1999; Daniel et al., 2002; Kartiwi, 2006)

(Kuzic et al., 2002; Ghandour et al., 2007)

(Bakos, 1991; Neches et al., 1994; Vladimir, 1996; Tan and Teo, 1998; Tetteh, 1999; Rashid, 2001; Jennex et al., 2004; Cloete et al., 2002; Jennex, 2003)

(Clarke, 1993; Vladimir, 1996; Cloete et al., 2002; Jennex et al., 2004; Sharma and Wickramasinghe, 2004; Tan and Ouyang, 2004; Auer, 2004; Him and Subramaniam, 2004; Chau and Turner, 2004)

(Tan and Teo, 1998; Ling, 2001; Daniel and Grimshaw, 2002; Buhalis and Deimezi, 2003; Purcell et al., 2004) (Rashid, 2001; Jennex et al., 2004)

(Bakos, 1991; Jennex et al., 2004; Kuzic et al., 2002; Buhalis and Deimezi, 2003; Purcell et al., 2004; Golden et al., 2004)

(Him and Subramaniam, 2004; Huy and Filiatrault, 2006; Jennex et al., 2004; Daniel et al., 2002; Kuzic et al., 2002; Buhalis and Deimezi, 2003; Sharma and Wickramasinghe, 2004; Piscitello and Sgobbi, 2004; Purcell et al., 2004)

(Quayle, 2002; Golden et al., 2004)

(Vladimir, 1996; Molla and Licker, 2001; Jennex et al., 2004; Torkzadeh and Dhillon, 2002; Golden et al., 2004; Lomerson et al., 2004; Abbasi et al., 2010; Ghandour et al., 2007)

(Molla and Licker 2001; Bakos 1991; Teo et al., 1997; Lowry et al., 1999; Jennex et al., 2004; Torkzadeh and Dhillon, 2002)

(Lowry et al., 1999; Sung, 2006; Brown, 2002; Abbasi et al., 2010; Ghandour et al., 2007)

(Torkzadeh and Dhillon, 2002; Sung, 2006; Brown, 2002; Abbasi et al., 2010; Ghandour et al., 2007)

(Lowry et al., 1999; Ghandour et al., 2007; Molla and Licker, 2001)

(Molla and Licker, 2001; Ghandour et al., 2007)

(Vladimir, 1996; Lowry et al., 1999; Kuzic et al., 2002; Ghandour et al., 2007)

(Ling, 2001; Sung, 2006)

(Molla and Licker, 2001; Torkzadeh and Dhillon, 2002; Sung, 2006; Vladimir, 1996; Golden et al., 2004; Lowry et al., 1999)

(Tetteh, 1999; Rashid, 2001)

(Neches et al., 1994; Teo et al., 1997; Jennex et al., 2004; Jennex, 2003; Sharma and Wickramasinghe, 2004;

Chau and Turner, 2004; Him and Subramaniam, 2004 ; Tan and Ouyang, 2004; Kartiwi, 2006; Huy and Filiatrault, 2006)

(Tetteh, 1999; Ling, 2001; Piscitello and Sgobbi, 2004)

(Ling, 2001; Jennex et al., 2004; Tan and Ouyang, 2004; Purcell et al., 2004)

(Kuzic et al., 2002; Le and Koh, 2002; Dholakia and Kshetri, 2004; Huy and Filiatrault, 2006)

(Lowry et al., 1999; Kuzic et al., 2002; Buhalis and Deimezi, 2003; Dholakia and Kshetri, 2004; Sharma and Wickramasinghe, 2004; Todd and Javalgi, 2007)

(Harris et al., 2003; Schlager et al., 2006; Suh and Han, 2003; McKnight and Chervany, 2001; Katsikas et al., 2005; Udo, 2001; Hoeren, 2000; Turner et al., 2001; Zhang et al., 2012)

(Harris et al., 2003; Schlager et al., 2006; Suh and Han, 2003; McKnight and Chervany, 2001; Katsikas et al., 2005; Udo, 2001; Hoeren, 2000; Turner et al., 2001; Zhang et al., 2012)

(Harris et al., 2003; Schlager et al., 2006; Liu et al., 2005)

(Liu et al., 2005; Harris et al., 2003; Belanger et al., 2002; Udo, 2001; Kim et al., 2008; Suh and Han, 2003; Schlager et al., 2006 ; Teo and Liu, 2007)

(Liu et al., 2005; Harris et al., 2003; Belanger et al., 2002; Udo 2001; Kim et al., 2008; Kim et al., 2010)

(Liu et al., 2005; Harris et al., 2003; Belanger et al., 2002; Udo 2001; Kim et al., 2008; Kim et al., 2010; Pavlou, 2003; McKnight and Chervany, 2001)

(Liu et al., 2005; Harris et al., 2003; Belanger et al., 2002; McKnight and Chervany 2001; Katsikas et al., 2005)

(Ladson and Fraunholz, 2005; Liu et al., 2005; Harris et al., 2003; Belanger et al., 2002; Katsikas et al., 2005) (Katsikas et al., 2005; McKnight et al., 2002; Zhang et al., 2012)

\subsection{Technological factors}

The research literature identifies a number of technological-related factors that influence ecommerce adoption in SMEs. Technical infrastructure involves intranet, extranet, email, and all technologies related infrastructures, that are necessary for the implementation of e-commerce.

Business Infrastructure: For any business to start using e-commerce there is a need for a business infrastructure that becomes the basis of the ecommerce implementation within the company (Gilaninia et al., 2011). According to Jennex et al. (2004), attributes of business infrastructure consist of a business plan, an in-place business organization, business processes, cost/cast control processes, advertising, client contact methods, and a payment process.

Communications: Network technologies for communications include TCP/IP, which is a protocol used to create and transfer information packets across the Internet; HTTP (Hypertext Transfer Protocol), which is a set of rules for transferring files over the Internet; and POP (Post Office Protocol), SMTP (Simple Mail Transfer Protocol), IMAP (Internet Message Access Protocol) that manages emails and network management issues such as Quality of Service (QOS) (Ngai and Wat, 2002) 


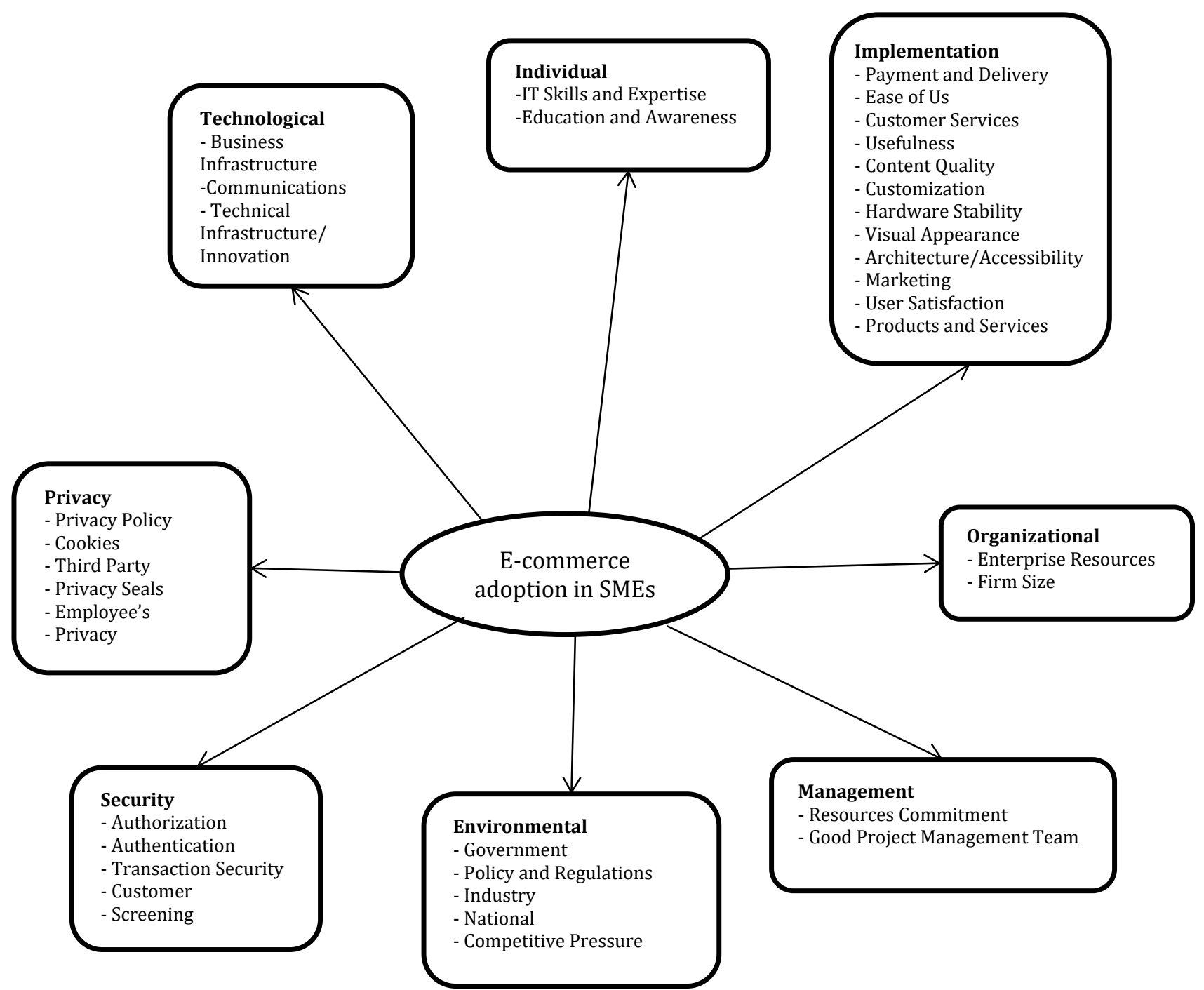

Fig. 4: Conceptual framework for E-commerce Success factors in SMEs

Innovation: Innovation considers to be the most commonly investigated characteristics to promote the adoption of technology (Chong et al., 2001). The factors of innovation were developed by Rogers (1995) and are adopted as a perceived relative advantage (the perceived benefits and impact of ecommerce), complexity (ease of use or learning ecommerce), trial ability (the degree by which ecommerce can be pilot tested or experimented), compatibility (both technical and organizational), and observability (the extent to which e-commerce benefit or gain is clear) (Chong et al., 2001; Huy and Filiatrault, 2006).

\subsection{Individual factors}

People are the most important factor in the implementation of e-commerce. Human factors can be divided amongst customers, staff, and top management, as they are the people mostly affected by the change.

IT Skills and Expertise: One of the major internal issues related to the non-adoption of e-commerce, is the lack of staff expertise and commitment (Tan and Teo, 1998; Dholakia and Kshetri, 2004; Zaied, 2012). Adopting new technologies requires change in employee work attitude, qualifications, performance, and knowledge of e-commerce technology (Huy and Filiatrault, 2006; Zaied, 2012). Therefore, management commitment is crucial; where skills need to be redefined and adequate training is needed (Cloete et al., 2002; Ghobakhloo and Tang, 2015). There is always a need for appropriate training to guide users (i.e. company staff) to prevent hesitation and confusion of new systems (Saif-Ur-Rehman, 2016). Seminars, lectures, and internal workshops, can be conducted to make users aware of system functions, in order to eliminate this hesitation or confusion.

Education and Awareness: Employees that already know about e-commerce within organizations may be more disposed to adapt to ecommerce (Huy and Filiatrault, 2006). Knowledge of information technology and e-commerce possessed by managers has an effect on adoption of ecommerce and influences the usage of e-commerce within an organization (Rashid and Al-Qirim, 2001; Huy and Filiatrault, 2006).

\subsection{Implementation factors}

According to Kartiwi (2006), implementation consists of a website development loop, which comes after the initial assessment of e-commerce adoption 
is done. This involves three stages; firstly, the product catalogue, company profile, and contact us are created; secondly, order forms and order tracking; and thirdly, online payments and customer services. This is similar with Daniel et al. (2002) paper, where online ordering and payment services are considered as being the most advanced level of website adoption. According to Ngai and Wat (2002), from a business process perspective, e-commerce is the application of technology towards the automation of business transactions and workflow. This includes payment and delivery systems, innovation, e-catalogues, search engines, shopping carts, communications, marketing, and advertising.

Payment and Delivery Methods: In agreement with Daniel et al. (2002), Sharma and Wickramasinghe (2004), Kartiwi (2006), Lomerson et al. (2004), online ordering and delivery is the most advanced stage in development and implementation of e-commerce. It is important if the business wants to use their website for more than just marketing purposes. This includes the method or system that is used to exchange payments between sellers and buyers (Al-Fayoumi et al., 2010; Zhang and Wang, 2014). This exchange of payment in e-commerce is done using a digital financial instrument, such as a credit/debit card, e-checks, ecash, etc. (Ngai and Wat, 2002; Chen et al., 2014).

The electronic shopping cart is order-processing software that acts as a shopping cart in physical world (i.e., where customers accumulate items while shopping). This shopping cart allows users to select various items, review item, make changes, finalize their list, and click the buy button to actually purchase the products.

Ease of Use: There are three types of ease of use, namely ease of understanding, ease of finding, and information focusing. Ease of use can be based on the simplification of the work process, by making use of e-commerce that help companies to accept it faster. Ease of use can be based on the ease of taking an order, payment, and information search (Abbasi et al., 2010; Woodside et al., 2011; Sambhanthan and Good, 2013).

Customer Services (Service Quality): The researcher observed that strong customer support and relationships with clients helped business clients to facilitate the adoption and implementation of an e-commerce system (Laosethakul and Boulton, 2007). Service quality is defined by the overall support and service delivered by the e-commerce service provider (Molla and Licker, 2001). Service quality influences the customer's intention to use a system, which may equally apply to their intention to continue using a system. Service quality has positive effects on user satisfaction with an e-commerce system (Brown and Jayakody, 2008).

Usefulness in term of Number of Hits: Perceived usefulness has a positive effect on continuance intention for an e-commerce system (Brown and Jayakody, 2008). Perceived usefulness is considered as being a key determinant for influencing customer's attention to continue using an e- commerce system. The use of e-commerce systems is a widely used criterion for accessing success. Use level, as captured through hits and visits, is often used to indicate market share and reach of ecommerce peacemakers, like Amazon and Yahoo (Molla and Licker, 2001; Sambhanthan and Good, 2013).

Content Quality (Detailed Product specification): Web comments should be completed, personalized, relevant, easy to understand, and secure (DeLone and McLean, 2003). The quality of the content and the extent to which that content meets the needs and expectations of customers, might affect the success of an organization and determine whether they stay on a site or move to the next site; which is only one click away (Molla and Licker, 2001; Hande and Ghosh, 2015).

Customization: Customization mean personalization of company products and services according to customer need (Schmitt and Bergmann, 1999). Internet to build interaction that not only attract but also engage and retain website visitor, learn (i.e. capture visitors profile) and relate (i.e. personalizing information) to their individual preference (Kierzkowski et al., 1996; Le and Koh, 2002; Goi, 2012). Product customization can dismiss customers risk in e-commerce transaction by dismissing the scope of the customer test on delivered products and lowering the possibility of finding unexpected features after delivery (Cho, 2006; Jahanshahi et al., 2013).

Hardware and Software Stability: Hardware and software stability is part of system quality (Molla and Licker, 2001). Hardware and software should be stable for consumer at all time to build their trust on company services.

Page Loading Speed: On internet where competitor are only few click away, it is necessary to have good page loading otherwise consumer will move to another site to make their purchases.

Visual Appearance: According to Fogg et al. (2003), Cyr (2008) and Kim and Zhang (2014) average consumer paid far more attention to superficial aspects of the website such as visual cues, than to its contents and the appeal of overall visual design was the largest among respondents.

System Architecture: System architecture should be good that is easy to use and maintained by not only consumer but also business personnel.

System 24 hour availability and accessibility: system should be available for 24/7 to build stability and allow consumer to make purchases regardless of time, distance concerns (Dickinger and Stangl, 2011; Goi, 2012).

System Accessibility (System quality): Ecommerce system quality can be determined via 24 hour availability, stability of software and hardware, page loading speed, system architecture, visual appearance, and accessibility as part of the ecommerce system quality (Molla and Licker, 2001; Woodside et al., 2011).

Marketing/Advertising: Electronic marketing can be viewed as a new modern practice of buying and 
selling goods, services, knowledge, and ideas via the Internet or other electronic means.

As with business and commerce, companies need to promote their e-business and e-commerce. Companies can make use of conventional media or Internet media. There is a need for company customers to know that the website exists, and therefore, there is a need for marketing to bring people to their website. There are several ways to accomplish Internet marketing. These include display advertising, such as a banner, where advertisers pay to display the banner of their website for certain amount of the time, which is used to promote company products and services. E-mail marketing, including the sending of e-mails to customers, in order to advertise their services online. Affiliate marketing; where a company hires another company or website (known as affiliates) to promote their products and services. The affiliate receives a commission or reward for every visitor, subscriber, sale or customer that they bring to the company.

User Satisfaction: User satisfaction is a means of measuring customer opinion of e-commerce systems and covers the entire cycle of the customer's experience; from information retrieval through to purchase, payment, receipt, and services (DeLone and McLean, 2003).

Products and Services: All companies believe that their product offerings have a positive impact on the success of their e-business. Trials of such products identified by companies include information rich (56\%), customizable (32\%), tangible (28\%), unique (24\%), web-based (20\%), and digitally based (20\%) products (Golden et al., 2004).

According to Vladimir (1996), products also include and need proper online marketing. These enabling services include e-catalogues, e-money, digital libraries, copyright protection, and digital authentication services (Vladimir, 1996).

Electronic catalogues are used to promote products and services. For customers, they are used to search for information on products and services. E-catalogue consists of a product database, directory, and a presentation function. E-catalogues can be used in combination with search engines (a search engine is a computer program that can access an Internet repository for specific information/keywords, retrieve it, and report the results).

Variety, Quality, and Cost of Products and Services: The Internet enables consumers to compare prices, products, and services, across suppliers. Price comparisons between different websites can lead to increased price competition and lower prices for products and services. An expansion into related product lines and increasing quality is also a good strategy. By making use of the internet, companies collect information on their target audience, identify target consumers, and better introduce products and services to targeted consumers (Shin, 2001).

\subsection{Organizational factors}

Organizational factors, also known as firm internal factors, are generally represented by size, quality of IS system, management support, and enterprise resources (Rashid and Al-Qirim, 2001; Dong-Jenn et al., 2012).

Enterprise Resources: Enterprise resources, also known as firm resources, include financial and technical resources that are principal facilitators during the implementation of e-commerce in any firm (Rashid and Al-Qirim, 2001; Huy and Filiatrault, 2006). Firm Size: The size of the firm also has a major impact on the manager's decision to adopt ecommerce (Tetteh, 1999; Dholakia and Kshetri, 2004; Huy and Filiatrault, 2006).

\subsection{Management factors}

Management support is one of the most important factors towards the adoption of ecommerce in companies (Saif-Ur-Rehman, 2016). Poon and Swatman (1999) emphasised the importance of the CEO/management role on EC adoption and diffusion. CEO innovativeness, IT knowledge and attitude, together with the perception of the manager (Grandon and Pearson, 2004; Abdul Hameed and Counsell, 2012; Seyal et al., 2012), has a positive effective on e-commerce adoption.

Resources Commitment: These cases show a broad range of international web use demonstrated at different levels of resources commitment, functional sophistication involving information interaction, transaction, web-enabled business, and cultural adaption, such as language (Tiessen et al., 2001).

Good Project Management Team: The project management team should be efficient enough to develop the e-commerce site according to the business and client's needs and requirements (Moloney, 2015).

\subsection{Environmental factors}

The external environment plays an important role in the adoption of technology. These environmental factors consist of competitive pressure, supplier/buyer pressure, public policy, and the government's role (Rashid and Al-Qirim, 2001; Vaithianathan, 2010).

Government Policy and Regulations: According to Jennex et al. (2004) the regulatory environment attribute involves legal representative/support, cost advantage exists, intellectual property protection, tax law encouraging B2B/e-commerce, banking/wire transfer law supporting overseas/electronic payments, customs laws supporting global ecommerce, exchange rules/rates favourable, and telecom regulation favour business. There should be proper government support towards the implementation of e-commerce, where the 
respective government supports and encourages small businesses towards the adoption of ecommerce (AlGhamdi et al, 2013; Zhang and Okoroafo, 2013; Neely, 2014). In the UK, the government has set rules and regulations that include intellectual property rights linked to ecommerce, including trademarks, domain name registration, copyrights, and patents (Jennex et al., 2004; Turban and King, 2004; AlGhamdi et al., 2011).

Industry: According to Ling (2001), every adoption and diffusion of e-commerce varies from industry to industry, as industry considers that external factors compromise much wider aspects, including competitive pressure, pressure from suppliers, and critical mass.

National: National can compromise factors such as the level of government support, national infrastructure, and cultural differences (Chong et al., 2001). According to Efendioglu and Yip (2004), Kang and Corbitt (2002), Laosethakul and Boulton (2007), Pavlou and Chai (2002), and Thatcher et al., (2006), findings from cultural factor research are beneficial for IS developers for catering domestic customer base, as well as the international market, with a specific understanding of culture and human behaviour that it produces.

Competitive Pressure: Competitive pressure is a major influence in the adoption of e-commerce (Dholakia and Kshetri, 2004; Huy and Filiatrault, 2006; Chiou et al., 2010). One of the major benefits of e-commerce is its competitive advantage (Kuzic et al., 2002). According to research by Dholakia and Kshetri (2004), in order to move websites further towards internet usage, they should focus on the firm who holds other related technologies and has a particular belief regarding competitive behaviour. The number of firms using websites for customer services and market research will impact the perception of competitive pressure and further accelerate SMEs towards the adoption of ecommerce (Dholakia and Kshetri, 2004).

\subsection{Security factors}

According to Kalakota and Whinston (1996), Shahibi and Fakeh (2011), Zhang and Okoroafo (2013), a security threat is defined as a circumstance, condition, event with the potential to cause economic hardship to data or network resources in the form of destruction, disclosure, modification of data, denial of service, and/or fraud, waste and abuse. Security thus pertains to protection against these threats; security in e-commerce is reflected in the technologies used to protect and secure customer data (Belanger et al., 2002; Ling et al., 2011).

Authorisation (Protection of a site from unauthorised outsiders): Access Rights should be granted on a need-to-know basis; security patches should be applied as soon as possible; sensitive or confidential data should be encrypted; web servers, network equipment, and other infrastructure components should be physically protected (Hansel and Vianna, 2016). Security best practices should be implemented as recommended by organisations such as the network security should be audited regularly by someone who specialises in intrusion detection and prevention (Awa et al., 2015).

Authentication: Authentication ensures that the trading parties in an electronic transaction or communication are in fact who they claim to be (Suh and Han, 2003; Aldás-Manzano et al., 2009; Polasik and Piotr Wisniewski, 2009). The authentication can be implemented by some of the technology such as identity certificates, Public-Key Infrastructure (PKI), Privilege Management System (PMI) (Katsikas et al., 2005; Liu et al., 2008).

Transaction Security: Transaction security depends on the confidentiality of information between seller and buyer and non-repudiation that becomes even more important during the execution phase where secure payment is ensured as well as the secure delivery of the good (Shahibi and Fakeh, 2011). Therefore, according to Katsikas et al. (2005) and Moloney (2015) e-commerce security requirement depends on confidentiality, the integrity and availability of information and system, the authenticity of communication parties and the non-repudiation sources.

Customer Screening: This is essential in order to protect a system from unauthorised access and can be done using a firewall and terminal, database, server, application, and operating system security measures (Suh and Han, 2003).

Data Security Policy: The first step in securing entity, electronic data and the system involves a design security policy. Security policies are important because they define what is being protected and what type of restriction should be put on those controls (Smith, 2004).

\subsection{Privacy factors}

Privacy is "the condition of not having undocumented personal knowledge about one possessed by others" (Parent, 1983; Ohlhausen and Okuliar, 2015). Privacy related to issues of concern for both current and prospective e-commerce customers (Lanier and Saini, 2008; Shah et al., 2013). There are a number of ways in which individual information can be found on the Internet, such as reading individual entries on a newsgroup posting; looking at individual names and identities in the Internet directory; by reading emails, conducting surveillance on employees, wiretapping wireless and listening to employees; asking an individual to complete website registration, and gathering information on individuals while they access the website by making use of cookies (Turban and King, 2004; Karakaya and Stark, 2013; Chen and Liu, 2015).

According to Harrison et al. (2002) and Đkudienë et al. (2015), e-commerce allows for the maintenance of trust and development of relations with online clients such as privacy policy and thirdpart privacy seals, interacting with customers, 
reputation building, links to other sites and guarantees or other seals.

Privacy Policy: An online privacy policy or OOP is often used by a website to provide a comprehensive description of their information practices (Antón and Earp, 2001). It informs users that their privacy rights are being considered and that the website understands the privacy concern faced by users (Ladson and Fraunholz, 2005). The information practices reflected in the firm's privacy policy should be open and honest, thus giving users the opportunity to evaluate the practices and make informed decisions regarding whether or not to disclose their personal information (Culnan and Bies, 2003). A website with a privacy policy will reassure consumers that the vendor is ethical, thus meaning that these consumers will be more willing to share information (McKnight and Chervany, 2001; Shah et al., 2013). This will lead to an increase in repeat visits and more purchases (Liu et al., 2005).

Cookies: Cookies and tracking software are used to follow consumers' online activities so as to gather information about their personal interests and preferences. This information is extremely valuable as it helps a company to sell customers the products and services tailored to their needs (Liu et al., 2005). According to Privacy and Electronic Communication Regulation, businesses have to inform their customers that they use cookies, and provide a choice for user who do not want to accept it; this means providing users with a statement of privacy and cookies which tell them how they are being used and how they can be switched off by the users (Turban and King, 2004).

Third Party Privacy Seals: Third party seals are increasingly used by businesses to communicate their commitment to security (e.g. Verisign) (Belanger et al., 2002). Groups like TRUSTe or BBBOnline, AICPA's Webtrust or SysTrust and Entertainment Software Board Real (ESRB) offer programs in which businesses can participate in order to show their commitment to privacy and security. Privacy seals offer a readily visible and easy way to reassure consumers that the online business respects individual privacy on the Internet (Liu et al., 2005; Andreani, 2016).

Employee's Privacy: In some cases technology has transformed arrangements, thus meaning that people can connect to company intranets from home. The growth of mobile Internet, whereby employees can access information on the move, has piled additional pressure on the security system (Harris et al., 2003). With this in mind, there should be a code of conduct for employees using a system that ensures privacy and security of consumer data. It is also not ethical for a company to access their employees' data and emails without their consent, and as such measures should be provided to protect individual employee privacy (Karakaya and Stark, 2013).

Organisations are educating their employees and provide necessary hardware and software that enhances user privacy. For example, if an organisation informs its employees of its policy and intention to monitor e-mails as well as the consequences of sending and/or receiving e-mails, considered inappropriate, then the employee may cut down on the number of such emails, and the organisation will have achieved their goals (Udo, 2001)

\section{Limitations and future research}

This paper explains the overall structure of ecommerce and its various factors using research conducted over the past 22 years in this area. There is a need to consider these factors, when ecommerce is being implemented in any organization. The success factors and sub-factors identified in this paper highlight the major obstacles and motivations towards the implementation of e-commerce. This paper helps to identify the strongest and weakest points, in order to close the research gap, and thus, propose the best way to implement e-commerce within SMEs. Even though this review is not considered as being exhaustive, as it only covers 40 research papers in this area; it does provide particular insights into the different factors of ecommerce that define the success of e-commerce in any business/organization. Despite these limitations, and given that the reviewed studies represent more than a decade of research; the conceptual model presented makes this literature review imperative. This model will prove to be of interest and value for practicing managers, SMEs owners, and those seeking to adopt and implement e-commerce strategies. Further research will be performed to validate and empirically test the model. Furthermore, the model will be implemented into various SMEs to calculate the success of factors and their sub-factors. Based on the analyses and opinion of those SMEs, the model will be further modified.

\section{Conclusion and research implications}

Despite the recent boom and crash of the dot.com industry, e-commerce is still thriving. Recent European and North America statistics show that ecommerce is experiencing a stable, upward growth, by providing numerous benefits to customers, companies, and society at large. Our review of the last 20 years has helped to develop a conceptual model that will allow SMEs to successfully implement e-commerce within their organization. While some studies have been conducted on the usage of certain models in large companies; applications within SMEs have still remained largely un-locked. Extensive research is still needed to understand the successful adoption of e-commerce within SMEs. We believe that our work provides a further step in this direction. We feel the results presented in this research have several important implications.

1) E-commerce research continues to increase significantly over the years but the focus will be more on security and privacy issues of e-commerce. 
2) There should be more paper that should deal with public policy. Interestingly there was not much paper on privacy, legal, ethics and intellectual property policies. These are topic and issues should be on top of the list as they are the important pillar that supports e-commerce applications in businesses.

3) The papers on the technical standard were very hard to find. The articles related to standards, interface, information publishing tools and transport. However, these standards are important to ensure compatibility across the entire network are also important pillars of e-commerce.

\section{References}

Abbasi MR, Sarlak MA, Ghorbani A, and Esfanjani HA (2010). CSFs of e-commerce admission in small and medium size enterprises (SMEs). African Journal of Business Management, 4(16): 3480-3490.

Abdul Hameed M and Counsell S (2012). Assessing the influence of environmental and CEO characteristics for adoption of information technology in organizations. Journal of Technology Management and Innovation, 7(1): 64-84.

ABS (2013). Statistics. Australian Bureau of Statistics (Government Agency), Canberra, Australia. Available online at: http://www.abs.gov.au/

Aldás-Manzano J, Lassala-Navarre C, Ruiz-Mafe C, and Sanz-Blas S (2009). The role of consumer innovativeness and perceived risk in online banking usage. International Journal of Bank Marketing, 27(1): 53-75.

Ale Ebrahim N, Ahmed S, Rashid A, Hanim S, and Taha Z (2010). The Effectiveness of Virtual R\&D Teams in SMEs: Experiences of Malaysian SMEs. In the $11^{\text {th }}$ Asia Pacific Industrial Engineering and Management Systems Conference, Melaka, Malaysia. Available online at: http://ssrn.com/abstract= 1728284

Al-Fayoumi M, Aboud S, Al-Fayoumi M, and Jedda KSA (2010). Practical e-payment scheme. International Journal of Computer Science Issues, 7(3): 18-23.

AlGhamdi R, Drew S, and Al-Ghaith W (2011). Factors influencing e-commerce adoption by retailers in Saudi-Arabia: A qualitative analysis. The Electronic Journal of Information Systems in Developing Countries, 47(7): 1-23.

AlGhamdi R, Nguyen A, and Jones V (2013). A study of influential factors in the adoption and diffusion of B2C e-commerce. International Journal of Advanced Computer Science and Applications, 4(1): 89-94

Andreani JC (2016). What third parties do people trust when they do not know each other? a crowdfunding experimentation. PhD Dissertation, Tata Institute of Social Sciences, Mumbai, India.

Antón AI and Earp JB (2001). A taxonomy for web site privacy requirements. Technical Report NO. 2001-14, North Carolina State University at Raleigh, Raleigh, USA.

Anumba CJ and Ruikar K (2002). Electronic commerce in construction--trends and prospects. Automation in Construction, 11(3): 265-275.

Auer C (2004). E-Transformation of Austrain SMEs: A concept that fits the reality. In: Al-Qirim NA (Ed.), Electronic Commerce in Small to Medium-Sized Enterprises: Frameworks, Issues and Implications: 216-230. Idea Group Publishing, USA.

Awa HO, Ojiabo OU, and Emecheta BC (2015). Integrating TAM, TPB and TOE frameworks and expanding their characteristic constructs for e-commerce adoption by SMEs. Journal of Science and Technology Policy Management, 6(1): 76-94.
Ayyagari M, Beck T, and Demirguc-Kunt A (2007). Small and medium enterprises across the globe. Small Business Economics, 29(4): 415-434.

Bakos JY (1991). A strategic analysis of electronic marketplaces. MIS Quarterly, 15(3): 295-310.

Belanger F, Hiller JS, and Smith WJ (2002). Trustworthiness in electronic commerce: the role of privacy, security, and site attributes. The Journal of Strategic Information Systems, 11(3): 245-270.

Brown I and Jayakody R (2008). B2C e-commerce success: A test and validation of a revised conceptual model. The Electronic Journal Information Systems Evaluation, 11(3): 167-184.

Brown IT (2002). Individual and technological factors affecting perceived ease of use of web-based learning technologies in a developing country. The Electronic Journal of Information Systems in Developing Countries, 9(5): 1-15.

Buhalis D and Deimezi O (2003). Information technology penetration and ecommerce developments in Greece, with a focus on small to medium-sized enterprises. Electronic Markets, 13(4): 309-324.

Chau SB and Turner P (2004). An SME experience of E-Commerce: Some considerations for policy. In: Corbitt BJ and Al-Qirim NA. (Eds.), e-Business, e-Government and Small and Medium-Size Enterprises: Opportunities and Challenges: Opportunities and Challenges. Idea Group Publishing, USA.

Chen L and Liu HW (2015). A review of privacy protection in ecommerce. Journal of Advanced Management Science, 3(1): 50-53.

Chen X, Li J, Ma J, Lou W, and Wong DS (2014). New and efficient conditional e-payment systems with transferability. Future Generation Computer Systems, 37: 252-258.

Chiou WC, Lin CC, and Perng C (2010). A strategic framework for website evaluation based on a review of the literature from 1995-2006. Information and Management, 47(5): 282-290.

Cho SE (2006). Factors affecting customer needs of geographical accessibility in electronic commerce. Electronic Commerce Research and Applications, 5(2): 131-139.

Chong S, Pervan G, and Bauer C (2001). Implementation success of internet-based electronic commerce for small-and mediumsized enterprises in Australia. In the $14^{\text {th }}$ International Bled Electronic Commerce Conference, Bled, Slovenia.

Clarke R (1993). EDI is but one element of electronic commerce. In the $6^{\text {th }}$ International EDI Conference, Bled, Slovenia. Available online at: http://www.aesharenet.com.au/

Cloete E, Courtney S, and Fintz J (2002). Small businesses' acceptance and adoption of e-commerce in the western cape province of South Africa. The Electronic Journal of Information Systems in Developing Countries, 10(4): 1-13

Culnan MJ and Bies RJ (2003). Consumer privacy: Balancing economic and justice considerations. Journal of Social Issues, 59(2): 323-342.

Cyr D (2008). Modeling web site design across cultures: relationships to trust, satisfaction, and e-loyalty. Journal of Management Information Systems, 24(4): 47-72.

Daniel EM and Grimshaw DJ (2002). An exploratory comparison of electronic commerce adoption in large and small enterprises. Journal of Information Technology, 17(3): 133-147.

Daniels E, Wilson H, and Myers A (2002). Adoption of e-commerce by SMEs in the UK. International Small Business Journal, 20(3): 253-270.

DeLone WH and McLean ER (2003). The DeLone and McLean model of information systems success: A ten-year update. Journal of Management Information Systems, 19(4): 9-30.

Dholakia RR and Kshetri N (2004). Factors impacting the adoption of the Internet among SMEs. Small Business Economics 23(4): 311-322. 
Dickinger A and Stangl B (2011). Online information search: differences between goal-directed and experiential search. Information Technology and Tourism, 13(3): 239-257.

Dong-Jenn Y, Dai-Hsu C, and Liu J (2012). A study of key success factors when applying e-commerce to the travel industry. International Journal of Business and Social Science, 3(8): 114-119.

Efendioglu AM and Yip VF (2004). Chinese culture and ecommerce: An exploratory study. Interacting with Computers, 16(1): 45-62.

Fogg BJ, Soohoo C, Danielson DR, Marable L, Stanford J, and Tauber ER (2003). How do users evaluate the credibility of Web sites? A study with over 2,500 participants. In the Conference of Designing for User Experiences (DUX'03), ACM, San Francisco, USA. https://doi.org/10.1145/997078.997097

Ghandour A, Benwell GL, and Deans KR (2007). The impact of leadership on eCommerce system success in small and medium enterprises context. In the Small Enterprise Conference: Building Sustainable Growth in SMEs, Small Enterprise, Hamilton, New Zealand. Available online at: http://hdl.handle.net/10523/723

Ghobakhloo M and Tang SH (2015). Information system success among manufacturing SMEs: Case of developing countries. Information Technology for Development, 21(4): 573-600.

Gilaninia S, Danesh SY, Amiri M, Mousavian SJ, and Eskandarpour $B$ (2011). Effective factors on adoption of e-commerce in SME cooperative. Interdisciplinary Journal of Contemporary Research in Business, 3(6): 13-21.

Goi CL (2012). A review of web evaluation criteria for e-commerce web sites. The Journal of Internet Banking and Commerce, 17(3): 1-10.

Golden W, Hughes M, and Ruane L (2004). Traits of successfully eenabled irish SMEs. In: Al-Qirim NA (Ed.), Electronic Commerce in Small to Medium-Sized Enterprises: Frameworks, Issues, and Implications: 165-178. Idea Group Publishing, USA.

Grandon EE and Pearson JM (2004). Electronic commerce adoption: An empirical study of small and medium US businesses. Information and Management 42(1): 197-216.

Hande PV and Ghosh D (2015). A comparative study on factors shaping buying behaviour on B2B and B2C E-Commerce platforms in India. Excel International Journal of Multidisciplinary Management Studies, 5(3): 1-10.

Hansel EP and Vianna RAA (2016). E-Commerce based payment system with authentication of electronic invoices. U.S. Patent 20,160,140,557.U.S. Patent and Trademark Office, Washington, USA.

Harris L, Coles AM, and Davies R (2003). Emerging ethical perspectives of e-commerce. Journal of Information, Communication and Ethics in Society, 1(1): 39-48.

Him LTW and Subramaniam R (2004). E-Commerce as a Business Enabler for Small and Medium Size Enterprises: Issues and Perspectives from Singapore. In: Corbitt BJ and Al-Qirim NA (Eds.), E-Business, e-government and small and medium-size enterprises: opportunities and challenges: 65-90. Idea Group Publishing, USA.

Hoeren T (2000). E-commerce-Germany: E-commerce and lawsome framementary thoughts for the future of internet regualtion from a German perspective. Computer Law and; Security Review, 16(2): 113-117.

Huy LV and Filiatrault P (2006). The adoption of e-commerce in SMEs in Vietnam: A study of users and prospectors. In the Pacific Asia Conference on Information Systems, AIS Electronic Library (AISeL), 74: 1335-1344. Available online at: http://aisel.aisnet.org/pacis2006?utm_source=aisel.aisnet.org \%2Fpacis2006\%2F74andutm_medium=PDFandutm_campaig $\mathrm{n}=\mathrm{PDFCoverPages}$
Jahanshahi AA, Zhang SX, and Brem A (2013). E-commerce for SMEs: Empirical insights from three countries. Journal of Small Business and Enterprise Development 20(4): 849-865.

Jennex M (2003). UNCTAD and E-commerce Success. The Electronic Journal of Information Systems in Developing Countries, 11(11): 1-7

Jennex ME, Amoroso D, and Adelakun O (2004). E-commerce infrastructure success factors for small companies in developing economies. Electronic Commerce Research, 4(3): 263-286.

Kalakota, R and Whinston AB (1996). Frontiers of electronic commerce. Addison Wesley Reading, Boston, USA.

Kang KS and Corbitt B (2002). Effectiveness of graphical components in web site e-commerce application-a cultural perspective. The Electronic Journal of Information Systems in Developing Countries, 7(1): 1-6.

Karakaya F and Stark SM (2013). Online Trust: Strategies to build confidence from a business perspective. Journal of Advanced Management and Business Research, 1(1): 1-10.

Karimov FP, Brengman M, Van Hove L, and Van L (2011). The effects of website design dimensions on initial trust: A synthesis of the empirical literature. Journal of Electronic Commerce Research, 12(4): 272-301.

Kartiwi M (2006). Case studies of e-Commerce adoption in Indonesian SMEs: The evaluation of strategic use. Australasian Journal of Information Systems, 14(1): 69-80

Katsikas SK, Lopez J, and Pernul G (2005). Trust, privacy and security in e-Business: Requirements and solutions. In: Bozanis $\mathrm{P}$ and Houstis EN (Eds.), Advances in Informatics: 548-558. Springer, Berlin, Germany.

Kierzkowski A, Mcquade S, Waitman R, and Zeisser M (1996). Current research: marketing to the digital consumer. The Mckinsey Quarterly, (2): 180-183. Available online at: https://www.questia.com/library/journal/1G155412125/current-research-marketing-to-the-digitalconsumer

Kim C, Tao W, Shin N, and Kim KS (2010). An empirical study of customers' perceptions of security and trust in e-payment systems. Electronic Commerce Research and Applications, 9(1): 84-95.

Kim DJ, Ferrin DL, and Rao HR (2008). A trust-based consumer decision-making model in electronic commerce: The role of trust, perceived risk, and their antecedents. Decision Support Systems, 44(2): 544-564.

Kim E and Zhang R (2014). Mediating role of initial trust on the relationship between website quality and purchase intention. In the Association for Information Systems Conference, Macon, USA: 1-6. Available online at: http: //saisconferencemgmt.org/proceedings/2014/KimZhang.pdf

Kosiur D (1997). Understanding electronic commerce. Microsoft Press, USA.

Kuzic J, Fisher J, and Scollary A (2002). Electronic commerce benefits, challenges and success factors in the Australian banking and finance industry. In the European Conference on Information Systems, AIS Electronic Library, Gdańsk, Poland 60: 1607-1616. Available online at: http://aisel.aisnet.org/ cgi/viewcontent.cgi?article $=1067 \&$ context $=$ ecis 2002

Ladson A and Fraunholz B (2005). Facilitating online privacy on eCommerce websites: An Australian experience. Journal of Information, Communication and Ethics in Society, 3(2): 5968.

Lanier JCD and Saini A (2008). Understanding consumer privacy: A review and future directions. Academy of Marketing Science Review, 12(2): 1-48.

Laosethakul K and Boulton W (2007). Critical success factors for e-commerce in Thailand: Cultural and infrastructural 
influences. The Electronic Journal of Information Systems in Developing Countries 30(2): 1-22.

Le TT and Koh AC (2002). A managerial perspective on electronic commerce development in Malaysia. Electronic Commerce Research, 2(1): 7-29.

Ling CY (2001). Model of factors influences on electronic commerce adoption and diffusion in small-and medium-sized enterprises. School of Information Systems, Curtin University of Technology, Perth, Australia. Available online at: http://esmaeilkhou.com/articles/53-Adoption-Diffusion.pdf.

Ling KC, Daud DB, Piew TH, Keoy KH, and Hassan P (2011). Perceived risk, perceived technology, online trust for the online purchase intention in Malaysia. International Journal of Business and Management, 6(6): 167-182.

Liu C, Marchewka JT, Lu J, and Yu CS (2005). Beyond concern-a privacy-trust-behavioral intention model of electronic commerce. Information and Management, 42(2): 289-304.

Liu H, Luo P, and Wang D (2008). A scalable authentication model based on public keys. Journal of Network and Computer Applications, 31(4): 375-386.

Lomerson WL, McGrath LC, and Schwager PH (2004). An examination of the benefits of e-business to small and medium size businesses. In the $7^{\text {th }}$ Annual Conference of the Southern Association for Information Systems, Savannah, USA, 1: 296303.

Lowry G, Singh M, and Scollary A (1999). Electronic commerce initiatives in Australia: identifying opportunity, meeting challenges, and measuring success. In the $10^{\text {th }}$ Australasian Conference on Information Systems, Wellington, New Zealand: 532-41.

Mazzarol $T$ (2015). SMEs engagement with e-commerce, ebusiness and e-marketing. Small Enterprise Research, 22(1): 79-90.

McGregor R and Vrazalic L (2007). SMEs and electronic commerce: An over view of our current knowledge. In: McGregor R (Ed.), E-Commerce in Regional Small to Medium Enterprises: 1-24. IGI Global, USA. https://doi.org /10.4018/978-1-59904-123-0.ch001

McKnight DH and Chervany NL (2001). What trust means in ecommerce customer relationships: an interdisciplinary conceptual typology. International Journal of Electronic Commerce, 6(2): 35-59.

McKnight DH, Choudhury V, and Kacmar C (2002). The impact of initial consumer trust on intentions to transact with a web site: a trust building model. The Journal of Strategic Information Systems, 11(3): 297-323.

Molla A and Licker PS (2001). E-commerce systems success: An attempt to extend and respecify the DeLone and McLean model of IS success. Journal of Electronic Commerce Research, 2(4): 131-141.

Moloney DJ (2015). A review of the critical success factors and challenges facing e-commerce in the clothing industry in South Africa. PhD Dissertation, Stellenbosch University, Stellenbosch, South Africa.

Neches R, Neches AL, Postel P, Tenenbaum JM, and Frank R (1994). Electronic Commerce on the Internet (No. ISI/RR-94385). USC/Information Sciences Institute, University of Southern California, Los Angeles, USA.

Neely PR (2014). The impact and implementation of e-Commerce in government and law enforcement. Journal of Management, 15(1): 92-103.

Neergaard P (1992). Microcomputers in small and medium-size companies: Benefits achieved and problems encountered. In the $3^{\text {rd }}$ Australian Conference on Information Systems, Wollongong, Australia: 579-604.
Ngai EWT and Wat FKT (2002). A literature review and classification of electronic commerce research. Information and Management 39(5): 415-429.

Ohlhausen MK and Okuliar A (2015). Competition, Consumer protection, and the right (approach) to privacy. Antitrust Law Journal, Forthcoming. Available online at: https://ssrn.com/abstract=2561563

Parent WA (1983). Privacy, morality, and the law. Philosophy and Public Affairs, 12(4): 269-288.

Pavlou PA (2003). Consumer acceptance of electronic commerce: Integrating trust and risk with the technology acceptance model. International Journal of Electronic Commerce, $7(3)$ : 101-134.

Pavlou PA and Chai L (2002). What drives electronic commerce across cultures? A cross-cultural empirical investigation of the theory of planned behavior. Journal of Electronic Commerce Research, 3(4): 240-253.

Perrini F, Russo A, and Tencati A (2007). CSR strategies of SMEs and large firms (Evidence from Italy). Journal of Business Ethics, 74(3): 285-300.

Piscitello L and Sgobbi F (2004). Globalisation, e-business and SMEs: Evidence from the Italian district of Prato. Small Business Economics, 22(5): 333-347.

Polasik M and Piotr Wisniewski T (2009). Empirical analysis of internet banking adoption in Poland. International Journal of Bank Marketing, 27(1): 32-52.

Poon S (2002). Have SMEs benefited from e-commerce?. Journal of Information Systems, 10(1): 66-72.

Poon S and Huang X (2004). E-commerce and SMEs: a reflection and the way ahead. In: Al- Qirim N (Ed.), Electronic Commerce in Small to Medium-Sized Enterprises: Frameworks, Issues and Implications: 17-29. Idea Group Publishing, USA.

Poon S and Swatman P (1999). An exploratory study of small business Internet commerce issues. Information and Management, 35(1): 9-18.

Purcell F, Toland J, and Huff SL (2004). The potential of ecommerce for remotely located SMEs: Case studies from Samoa. In: Al-Qirim NA (Ed.), Electronic Commerce in Small to Medium-Sized Enterprises: Frameworks, Issues and Implications: 86-105. Idea Group Publishing, USA.

Quayle M (2002). E-commerce: The challenge for UK SMEs in the twenty-first century. International Journal of Operations and Production Management, 22(10): 1148-1161.

Rashid MA (2001). E-commerce technology adoption framework by New Zealand small to medium size enterprises. Research Letters in the Information and Mathematical Sciences, 2: 6370 .

Rashid MA and Al-Qirim NA (2001). E-commerce technology adoption framework by New Zealand small to medium size enterprises. Research Letters in the Information and Mathematical Sciences, 2(1): 63-70.

Reichheld FF and Schefter P (2000). E-loyalty: your secret weapon on the web. Harvard Business Review, 78(4): 105-113.

Rogers EM (1995). Diffusion of Innovations: modifications of a model for telecommunications. In: Stoetzer MW and Mahler DKA (Eds.), Die Diffusion von Innovationen in der Telekommunikation: 25-38. Springer Berlin Heidelberg.

Saif-Ur-Rehman, R. A. (2016). A Study of Barriers to E-Commerce Adoption among SMEs in Malaysia. University of Modern Sciences, 1(1): 45-58.

Sambhanthan A and Good A (2013). Critical success factors for positive user experience in hotel websites: applying Herzberg's two factor theory for user experience modeling. International Journal of E-Services and Mobile Applications. Available online at: https://arxiv.org/pdf/1302.5196 
Savrul M, Incekara A, and Sener S (2014). The potential of Ecommerce for SMEs in a globalizing business environment. Procedia-Social and Behavioral Sciences, 150: 35-45.

Schlager C, Nowey T, and Montenegro JA (2006). A reference model for authentication and authorisation infrastructures respecting privacy and flexibility in b2c eCommerce. In the $1^{\text {st }}$ International Conference on Availability, Reliability and Security, IEEE, Vienna, Austria, Austria. https://doi.org /10.1109/ARES.2006.13

Schmitt S and Bergmann R (1999). Applying case-based reasoning technology for product selection and customization in electronic commerce environments. In the $12^{\text {th }}$ International Bled Electronic Commerce Conference, Global Networked Organizations, Bled, Slovenia, 273: 1-15.

Seyal AH, Yussof A, Mohammad A, and Rahman MNA (2012). Exploring CEO's leadership frames and e-commerce adoption among bruneian SMEs. The South East Asian Journal of Management, 6(1): 33-52.

Shah MH, Okeke R, and Ahmed R (2013). Issues of privacy and trust in e-commerce: Exploring customers' perspective. Journal of Basic and Applied Scientific Research, 3(3): 571577.

Shahibi MS and Fakeh SKW (2011). Security factor and trust in ecommerce transactions. Australian Journal of Basic and Applied Sciences, 5(12): 2028-2033.

Sharma SK and Wickramasinghe N (2004). Obstacles to SMEs for e-adoption in the Asia Pacific region. In: Corbitt $\mathrm{BJ}$ and $\mathrm{Al}$ Qirim NA (Eds.), E-Business, e-Government and Small and Medium-Sized Enterprises: Opportunities and Challenges: 112-133. Idea Group Publishing, USA.

Shin N (2001). Strategies for competitive advantage in electronic commerce. Journal of Electronic Commerce Research, 2(4): 164-171.

Smith AD (2004). E-security issues and policy development in an information-sharing and networked environment. Aslib Proceedings: 56(5): 272-285

Suh B and Han I (2003). The impact of customer trust and perception of security control on the acceptance of electronic commerce. International Journal of Electronic Commerce, 7(3): 135-161.

Sung TK (2006). E-commerce critical success factors: East vs. West. Technological Forecasting and Social Change, 73(9): 1161-1177.

Tan M and Teo TSH (1998). Factors influencing the adoption of the Internet. International Journal of Electronic Commerce, 2(3): 5-18.

Tan Z and Ouyang W (2004). Diffusion and impacts of the internet and E-commerce in China. Electronic Markets, 14(1): 25-35.

Teo TS, Tan M, and Buk WK (1997). A contingency model of Internet adoption in Singapore. International Journal of Electronic Commerce, 2(2): 95-118.

Teo TSH and Liu J (2007). Consumer trust in e-commerce in the United States, Singapore and China. Omega, 35(1): 22-38.

Tetteh EO (1999). From business networks to virtual organisation: A strategic approach to business environment transformation in online small and medium-sized enterprises. In the $10^{\text {th }}$ Australasian Conference on Information Systems: 980-992.
Thatcher SM, Foster W, and Zhu L (2006). B2B e-commerce adoption decisions in Taiwan: The interaction of cultural and other institutional factors. Electronic Commerce Research and Applications, 5(2): 92-104.

Tiessen JH, Wright RW, and Turner I (2001). A model of ecommerce use by internationalizing SMEs. Journal of International Management, 7(3): 211-233.

Todd PR and Javalgi RRG (2007). Internationalization of SMEs in India: Fostering entrepreneurship by leveraging information technology. International Journal of Emerging Markets, 2(2): 166-180.

Torkzadeh G and Dhillon G (2002). Measuring factors that influence the success of Internet commerce. Information Systems Research, 13(2): 187-204.

Turban E and King D (2004). Electronic commerce 2004: A managerial perspective. Prentice Hall, Upper Saddle River, USA.

Turban E, King D, and Lang J (2011). Introduction to Electronic Commerce. Pearson Education, Upper Saddle River, USA.

Turner CW, Zavod M, and Yurcik W (2001). Factors that affect the perception of security and privacy of e-commerce web sites. In the $4^{\text {th }}$ International Conference on Electronic Commerce Research, Dallas, Texas: 628-636.

Udo GJ (2001). Privacy and security concerns as major barriers for e-commerce: a survey study. Information Management and Computer Security, 9(4): 165-174.

Vaithianathan S (2010). A review of e-commerce literature on India and research agenda for the future. Electronic Commerce Research, 10(1): 83-97.

Vladimir Z (1996). Electronic commerce: Structures and issues. International Journal of Electronic Commerce, 1(1): 3-23.

Woodside AG, Ramos Mir V, and Duque M (2011). Tourism's destination dominance and marketing website usefulness. International Journal of Contemporary Hospitality Management, 23(4): 552-564.

Zaied ANH (2012). Barriers to e-commerce adoption in Egyptian SMEs. International Journal of Information Engineering and Electronic Business, 4(3): 9-18.

Zendehdel M and Paim LH (2012). Perceived risk of security and privacy in online shopping: A study of Malaysia context. Life Science Journal, 9(4): 983-987.

Zhang $\mathrm{H}$ and Okoroafo SC (2013). An e-commerce key success factors framework for Chinese SME exporters. International Journal of Economics and Finance, 6(1): 129-137.

Zhang Y and Wang R (2014). Comparison of E-payment of the B2C E-commerce in China from the security and trust perspective. International Journal of Security and Its Applications, 8(3): 325-338.

Zhang Y, Deng X, Wei D, and Deng Y (2012). Assessment of ecommerce security using AHP and evidential reasoning. Expert Systems with Applications, 39(3): 3611-3623.

Zhou M, Dresner M, and Windle RJ (2008). Online reputation systems: Design and strategic practices. Decision support systems, 44(4): 785-797. 